\title{
Fire Risk in Vegetation Contiguous to Highways of Access to the Industrial and Port Complex of Pecém/Ceará-Brazil: Case Study
}

\author{
Davi Teixeira Gomes ${ }^{1}$, Meiry Sayuri Sakamoto ${ }^{2}$
}

\footnotetext{
${ }^{1}$ Corpo de Bombeiros Militar do Ceará, Brasil

${ }^{2}$ Fundação Cearense de Meteorologia e Recursos Hídricos, Fortaleza, Ceará, Brasil

*e-mail: davi_tgomes@hotmail.com; meiry@funceme.br
}

\begin{abstract}
The risk of fire is related to the amount of ignition agents available from human sources and from natural causes of fire. The literature also indicates a significant relationship between the occurrence of fires and the distance from the nearest road. Thus, fires, particularly those near highways, can generate traffic disturbances, causing changes in demand and capacity, reducing average speed and, consequently, generating undesirable delays for road users, as well as contributing to causing disasters related to the transportation of passengers and cargo. This paper presents a study on the risk of fires in vegetation in areas adjacent to the main access roads to the industrial and port complex of Pecém, roads for the flow of raw materials and products. The study considered stretches of the federal highways BR-222 and BR-020 and the state highways CE-085 and the former highway CE-422, currently called CE-155, within the limits of the municipalities of São Gonçalo do Amarante and Caucaia, both belonging to the Metropolitan Region of Fortaleza, State of Ceará, Northern Coast of the Northeast. In the region there is a varied mosaic of landscapes according to local geoecological and climatological factors. There is a shortage of rainfall, low air and soil humidity, strong sunlight, high levels of evaporation and temperature, and vulnerability to climate change. Statistics were analyzed for records of hotspots identified by the processing of satellite images. To validate the foci, atmospheric data from ground meteorological stations and records of occurrences of the Military Fire Department of Ceará were analyzed. The analyses showed that forest fires and more than $70 \%$ of hotspots are identified in the period between the months of September and December. The study made it possible to map the areas with the highest incidence of fires, which require greater attention from the local community and from forest fire fighting institutions. These results are essential subsidies for the institutions responsible for preventing and fighting fires in vegetation, preventing and mitigating natural and technological disasters, and for the private sector to prepare Mutual Assistance Plans in the event of emergencies.
\end{abstract}

Keywords: Forest Fires, Road Transport, Remote Sensing, Civil Defense 